\title{
Improved method of isolating bacteria from joint fluids by the use of blood culture bottles
}

\author{
ROBERT VON ESSEN AND AIRA HÖLTTÄ \\ From the Rheumatism Foundation Hospital, Heinola, Finland
}

SUMMARY An analysis of 47 episodes of bacterial arthritis showed that applying a blood culture procedure to the culture of joint fluids gave positive results in 10 cases $(21 \%)$ that were negative by conventional methods. When follow up samples taken during antibiotic treatment were considered the proportion of false negatives eliminated rose to $40 \%$. The respective advantages $A$ of using a large volume of inoculum and a large volume of medium are that very low numbers of $₫$ viable bacteria in infected fluid can be detected, and that growth inhibitors are diluted.

Key words: synovial fluid, bacterial arthritis, septic arthritis, suppurative arthritis, purulent arthritis.

The details of synovial fluid (SF) culture are scarcely addressed in diagnostic microbiology texts. Neither is the subject developed beyond standard instructions for pus specimens in a recent handbook dealing specifically with diagnostic tests on joint fluid. ${ }^{1}$ Several years ago we became aware of the occasionally very sparse growth on plates inoculated with SF from bacterial arthritis. In most of these instances growth was confined to the area originally covered by the drop of SF, suggesting a low number of viable bacteria. Occasionally the opposite applied: growth was seen only immediately outside the primary area or along its very edge, suggesting some inhibitory factor in SF but not always related to antibiotic treatment. Postulating that some positive specimens might be missed altogether, we started to inoculate SF in bulk into blood culture bottles, in addition to the plates. We have previously published two unusual isolations accomplished only by this method. ${ }^{2}{ }^{3}$ Here we show that this technique is of importance also in the isolation of common pathogens.

\section{Materials and methods}

SF culture results for the 10 year period 1975-84 were reviewed. One thousand, four hundred and thirty nine specimens from slightly smaller numbers

Accepted for publication 21 November 1985 .

Correspondence to Dr Robert von Essen, Rheumatism Foundation Hospital, SF-18120 Heinola, Finland. of joints and patients had been cultured. Routinely, a drop of SF was inoculated on a sheep blood agars and a chocolate agar plate, incubated in air/ $\mathrm{CO}_{2}$ at $35^{\circ} \mathrm{C}$, and on a brucella agar plate incubated in an⿳亠丷⿵冂丶 anaerobic jar. All plates were held for a minimum of $48 \mathrm{~h}$. Specimens that had been regarded by the $\overrightarrow{\vec{A}}$ clinician with enough suspicion to state a reason for윽 his/her culture request, or were considered suspicious looking by the laboratory staff, were in addition inoculated into blood culture bottles (BCB), 0·1-5 ml/bottle, whenever sufficient SF was available. The bottles contained $45 \mathrm{ml}$ supplemented brain heart infusion broth, with polyan $\frac{3}{3}$. etholesulphonate as anticoagulant and $\beta$-lactamaseô and $p$-aminobenzoic acid as anti-antibiotics, in $20 \% ₹$ $\mathrm{CO}_{2} /$ air and $20 \% \quad \mathrm{CO}_{2} /$ nitrogen respectivelyo (Hemobact Aerobe and Hemobact Anaerobe, $D$ Orion Diagnostica, Espoo, Finland). Occasionally, for example at night, the bottles were injected at then bedside and later brought to the laboratory. The bottles were subcultured the day after inoculation $\tilde{S}^{-}$ and twice more at weekly intervals. Subcultures ${ }_{\omega}^{N}$ were performed as described for primary isolationo on plates. Two hundred and one of the specimenso were processed in BCB. If there was material left after culture the suspect fluids were Gram stained.? Recently they have been first stained with acridine orange ${ }^{4}$ and then restained if indicated.

\section{Results}

Positive isolations were obtained from 47 episodes of bacterial arthritis in 40 patients (16 male, 24\% 
Table 1 Type of infection, diagnosis* and joints involved.

\begin{tabular}{lcccc}
\hline Joint & $\begin{array}{l}\text { Early } \\
\text { postoperative }\end{array}$ & $\begin{array}{l}\text { Late } \\
\text { postoperative }\end{array}$ & $\begin{array}{l}\text { No } \\
\text { surgery }\end{array}$ & Total \\
\hline Hip prosthesis & 1 & 7 & & 8 \\
Knee prosthesis & $9 \dagger$ & 4 & $11 \S$ & 13 \\
Knee & $4 \ddagger$ & 0 & 3 & 3 \\
Ankle & 0 & 0 & 2 & 2 \\
Shoulder & 0 & 0 & 4 & 4 \\
Elbow & 0 & 0 & 0 & 1 \\
Wrist & 1 & 0 & 1 & 1 \\
Metacarpophalangeal & 0 & 0 & 21 & 47 \\
No of infections & 15 & 11 & 18 & 40 \\
No of patients & 13 & 9 & & \\
\hline
\end{tabular}

${ }^{*}$ All RA patients unless otherwise indicated.

tOne patient with OA.

$\ddagger$ One patient with OA and one with JRA.

§One patient with SLE, one with JRA. and one primary.

"One primary.

female). Three patients were children, aged 4, 9, and 13 years. The last two of these had juvenile rheumatoid arthritis. The age range of the adults was 24-76 years $(\bar{x} \pm S D=54 \pm 12 \cdot 3)$. Only two patients had no underlying disease; two had osteoarthrosis, one had systemic lupus erythematosus, the rest had rheumatoid arthritis (RA). Although rheumatoid patients do have a modestly increased incidence of bacterial arthritis, ${ }^{5}$ the numbers mainly reflect our hospital's primary role as a centre for inflammatory rheumatic disease. Table 1 shows the joints involved and the clinical backgrounds of the patients. No patient had involvement of more than one joint during each episode of infection.

Table 2 shows the detection rate of the $\mathrm{BCB}$ and of the conventional technique for the initial isolates. Follow up samples were available in 33 instances. Of these, follow up cultures were negative in six and reisolation of the offending pathogen was successful in the other 27: once in 17, twice in eight, seven times in one instance (Salm typhimurium), and eight times in another (Staph aureus). The positive reisolation results are detailed according to organism and isolation technique in Table 3. The Staph epidermidis isolates accepted as pathogens were either seen on direct staining, isolated repeatedly, or came from prosthetic joints. Thirty three $(70 \%)$ of the initial and $36(75 \%)$ of the follow up specimens from the positive cases were inoculated into BCB. Occasionally only a drop of fluid was available; those were mostly follow up samples. A more common reason why BCB were not used, however, was that the infection was either clinically unapparent or that at least word of the opposite failed to reach the laboratory.

Specimens positive by BCB only, often failed to show turbidity the next day. The second subculture was positive, though the first had been negative in three instances, one of which has been previously described. ${ }^{3}$ The other two, which grew Staph aureus, came from patients on antibiotic therapy. No

Table 2 Bacteriological findings: initial isolation

\begin{tabular}{|c|c|c|c|c|c|c|c|c|c|c|}
\hline \multirow[t]{3}{*}{ Bacterium } & \multicolumn{3}{|c|}{ Type of infection } & \multirow{3}{*}{$\begin{array}{l}\text { Direct } \\
\text { smear } \\
\text { positive }\end{array}$} & \multicolumn{6}{|c|}{ Blood culture bottles/solid media } \\
\hline & \multirow{2}{*}{$\begin{array}{l}\text { Early } \\
\text { postop. }\end{array}$} & \multirow{2}{*}{$\begin{array}{l}\text { Late } \\
\text { postop. }\end{array}$} & \multirow{2}{*}{$\begin{array}{l}\text { No } \\
\text { surgery }\end{array}$} & & \multicolumn{2}{|c|}{$+1-$} & \multirow[t]{2}{*}{$+1+$} & \multirow[t]{2}{*}{$N D+1+$} & \multicolumn{2}{|c|}{ Total } \\
\hline & & & & & No & $\%$ & & & $N o$ & $\%$ \\
\hline Staphylococcus aureus & 10 & 6 & 12 & 11 & $2^{\ddagger}$ & 7 & 16 & $10^{+}$ & 28 & 60 \\
\hline Staph epidermidis & 2 & 1 & 2 & 1 & 3 & 60 & 1 & 1 & 5 & 11 \\
\hline$\beta$-Haemolytic streptococcus, group A & & & 1 & 1 & & & & 1 & 1 & 2 \\
\hline$\beta$-Haemolytic streptococcus, group B & & 1 & & & 1 & 100 & & & 1 & 2 \\
\hline$\beta$-Haemolytic streptococcus, group G & & & 2 & & 1 & 50 & & 1 & 2 & 4 \\
\hline Enterococcus* & 2 & & & & 1 & 50 & & $1^{\ddagger}$ & 2 & 4 \\
\hline Pneumococcus & & & 2 & 1 & $1^{\mp}$ & 50 & 1 & & 2 & 4 \\
\hline Haemophilus influenzae & & 1 & & 1 & & & 1 & & 1 & 2 \\
\hline Escherichia coli & & 2 & & 1 & & & 2 & & 2 & 4 \\
\hline Salmonella typhimurium & & & 1 & 1 & & & 1 & & 1 & 2 \\
\hline Pseudomonas aeruginosa* & 1 & & & & & & 1 & & 1 & 2 \\
\hline Kingella kingae ${ }^{19}$ & & & 1 & & 1 & 100 & & & 1 & 2 \\
\hline Total & 15 & 11 & 21 & 17 & 10 & 21 & 23 & 14 & 47 & 100 \\
\hline
\end{tabular}

* = Double infection.

$+\mathrm{ND}=$ not done.

$\ddagger=$ One patient on antibiotics. 
Table 3 Bacteriological findings: follow up specimens

\begin{tabular}{|c|c|c|c|c|c|c|c|c|c|c|}
\hline \multirow[t]{3}{*}{ Bacterium } & \multicolumn{3}{|c|}{ Type of infection } & \multicolumn{6}{|c|}{ Blood culture bottles/solid media } & \multirow{3}{*}{ Total } \\
\hline & \multirow{2}{*}{$\begin{array}{l}\text { Early } \\
\text { postop. }\end{array}$} & \multirow{2}{*}{$\begin{array}{l}\text { Late } \\
\text { postop. }\end{array}$} & \multirow{2}{*}{$\begin{array}{l}\text { No } \\
\text { surgery }\end{array}$} & \multicolumn{2}{|c|}{$+1-$} & \multirow[t]{2}{*}{$+/+$} & \multirow[t]{2}{*}{$-1+$} & \multirow[t]{2}{*}{$+/ N D$} & \multirow[t]{2}{*}{$N D /+$} & \\
\hline & & & & No & $\%$ & & & & & \\
\hline Staph aureus & 6 & 3 & 7 & $8^{*}$ & 29 & 6 & 1 & 3 & 10 & 28 \\
\hline Staph epidemidis & 1 & & 2 & $3+$ & 60 & 1 & & & $1^{*}$ & 5 \\
\hline $\begin{array}{l}\beta \text {-Haemolytic streptococcus, } \\
\text { group } G\end{array}$ & & & 1 & & & & & & 1 & 1 \\
\hline Enterococcus & 1 & & & & & 1 & & & & 1 \\
\hline Pneumococcus & & & 1 & & & 1 & & & & 1 \\
\hline$H$ influenzae & & 1 & & 2 & 100 & & & & & 2 \\
\hline E coli & & 1 & & & & 1 & & & & 1 \\
\hline Salm typhimurium & & & 1 & 4 & 57 & 3 & & & & 7 \\
\hline$P$ aeruginosa & 2 & & & 2 & 100 & & & & & 2 \\
\hline Total & 10 & 5 & 12 & 19 & 40 & 13 & 1 & 3 & 12 & 48 \\
\hline
\end{tabular}

*One patient not on antibiotics.

†Two patients not on antibiotics.

case with growth delayed until the third subculture was included in the series, and only once was this pattern observed. (The bacterium was identified as Propionibacterium acnes. Its pathogenetic significance was considered unlikely, despite a recent report to the contrary..$^{6}$ )

Staining was carried out on 38 of the initial SF samples and was positive in 16 instances $(42 \%)$. Follow up samples were rarely positive by staining. Bacteria in general, and intracellular Gram negative ones in particular, were easier to detect in acridine orange than in Gram stained smears. Specimens containing sufficient bacteria to be positive by direct staining, i.e., $\approx 10^{5} / \mathrm{ml}\left(10^{8} / \mathrm{l}\right)$, generally contained enough viable organisms for direct sensitivity testing by the paper disc method to produce useful results overnight.

\section{Discussion}

Rapid aetiological diagnosis is crucial for the success of the treatment of bacterial arthritis, ${ }^{7}$ and it is not a particularly rare disease. In 1977, 224 cases of bacterial arthritis, as compared with 135 cases of acute osteomyelitis, 305 cases of bacterial meningitis, and 1104 cases of septicaemia, were treated in the Finnish hospitals, i.e., about five $/ 10^{5}$ population. ${ }^{8}$ In a Texan study bacterial arthritis was shown to be the most common and the second most common cause respectively of new cases of arthritis in a series from a general and a VA hospital. ${ }^{9}$ The figures hardly justify the prevailing lack of interest in SF culture, compared with the continuing development of, for example, blood culture procedures. ${ }^{10}$ In that field the importance of using a large inoculum volume was established long ago, ${ }^{11}$ and more recently the need for a corresponding $\frac{c}{\bar{p}}$ large medium volume to dilute natural and therapy related inhibiting factors has been realised. ${ }^{12}$ Urio doubtedly the various techniques under current development for removing antibiotics from bloo $\$$ more efficiently may be adaptable to other biolog cal fluids too.

A possible reason for the lack of interest is that apart from the well known difficulty in growing Neisseria gonorrhoeae from $\mathrm{SF}^{13}$ the problem insufficiently recognised. ${ }^{14}$ Most papers on the subject deal with bacterial arthritis, with the aetie ology issue, by definition, settled in advance. A fewp, mostly paediatric reports, have addressed instead purulent arthritis, and disclosed rates of undis̄ covered aetiology from 19 to $60 \% .^{15-22}$ In 1966 Nelson and Koontz actually proposed a method of the BCB type in order to improve the isolation rate which they considered inadequate. ${ }^{15}$ Apparently they did not apply it, and subsequently the idea seems to have been forgotten.

The need to pursue an active culture policy for joint fluids, particularly in rheumatoid patients, if whom the usual clinical and laboratory signs of infection are obscured by the underlying disease has been convincingly stressed. ${ }^{23}$ Ideally, we believe the protocol for all SF specimens, or at least a inflammatory ones, should include BCB inocule tion. As 14 (30\%) of our isolations were made wit plates only, we obviously do not practise our belief, considering the cost in labour and materials to be too high. Since the method of plates only seems on $80 \%$ effective a couple of isolations were probab missed due to this omission. For economy the BCB protocol could be modified, apparently without los by eliminating the last subculture. Although it might 
seem that the anaerobe part could also be left out, we would not recommend that. Anaerobe joint infections, though not common, do occur from time to time ${ }^{24}$ and may be particularly important in prosthetic joints. ${ }^{25}$ We have seen Bacteroides sepsis in connection with ulcerating rheumatoid nodules and also isolated this genus from joint fluid after the present series was closed. Moreover, parallel cultures help in distinguishing contaminants, particularly Staph epidermidis, from genuine infections.

We attribute our failure to isolate $N$ gonorrhoeae, the most commom cause of bacterial arthritis in the general population, ${ }^{1314}$ to the age group and lifestyle of our patients. Although the blood culture medium we used does not support growth of gonococci on its own, probably because of the inhibitory effect of polyanetholesulphonate, ${ }^{26}$ the addition of $5 \mathrm{ml}$ of blood, serum, or SF in place of inoculum will reverse that effect ( $T$ Raines, Orion Diagnostica, personal communication). For optimal isolation of gonococci from SF the use of a hypertonic sucrose medium has, however, been advanced. ${ }^{27}$

It might be argued that the advantage of the BCB method is peculiar to rheumatoid patients, their inflammatory defence mechanisms being as it were premobilised. This view would gain credibility if RA patients possessed increased resistance to bacterial arthritis, or if some unique pathogen were a major aetiological factor. RA patients, however, actually have a somewhat increased susceptibility to bacterial arthritis, and the aetiological agents, apart from $N$ gonorrhoeae, are the usual ones. ${ }^{5}$ In fact it seems possible that the diagnostic advantage of the BCB method could gain in importance when applied to previously healthy patients capable of a vigorous antibacterial response.

\section{References}

1 Gatter R A. A practical handbook of joint fluid analysis. Philadelphia: Lea and Febiger. 1984: 51-4.

2 Haapasaari J, von Essen R, Kahanpää A. Kostiala A A 1. Holmberg K. Ahlqvist J. Fungal arthritis simulating juvenile rheumatoid arthritis. $\mathrm{Br}$ Med J 1982: 285: 923-4.

3 Salminen I, von Essen R. Koota K. Nissinen A. A pitfall in purulent arthritis brought out in Kingella kingae infection of the knee. Ann Rheum Dis 1984: 43: 656-7.

4 Kronvall G. Myhre E. Differential staining of bacteria in clinical specimens using acridine orange buffered at low $\mathrm{pH}$. Acta Pathol Microbiol Immunol Scand /B/ 1977; 85: 249-54.
5 von Essen R. Leirisalo-Repo M. Hämäläinen M J. Infection in patients with rheumatoid arthritis with special reference to rheumatoid surgery. Ann Chir Gynaecol 1985; 74 (suppl 198): $110-7$.

6 Yocum R C, McArthur J, Petty B G, Diehl A M, Moench T R. Septic arthritis caused by Propionibacterium acnes. JAMA 1982; 248 1740-1.

7 Ho G, Su E Y. Therapy for septic arthritis. JAMA 1982; 247: 797-800.

8 Virtanen M, Peltola $\mathrm{H}$. Bacteremia and purulent meningitis in Finland. An analysis of positive blood and cerebrospinal fluid cultures in 1976-80. Duodecim 1982; 98: 1315-25.

9 Sharp J T, Lidsky M D, Duffy J, Duncan M W. Infectious arthritis. Arch Intern Med 1979; 139: 1125-30.

10 Balows A, Tilton R C, eds. Body fluids and infectious diseases. Clinical and microbiologic advances. Am J Med 1983; 75 (Suppl 1B).

11 Pulvertaft R J V. Bacterial blood cultures. Lancet 1930; i: 821-2.

12 Beebe J L, Bourne K A. Ellner P D. Effect of dilution on recovery of bacteria from blood. J Clin Microbiol 1977; 5: 448-52.

13 Eisenstein B I, Masi A T. Disseminated gonococcal infection (DGI) and gonococcal arthritis (GCA). I. Bacteriology, epidemiology, host factors, pathogen factors, and pathology. Semin Arthritis Rheum 1981; 10: 155-72.

14 Goldenberg D L, Reed J I. Bacterial arthritis. N Engl J Med 1985; 312: 764-71.

15 Nelson J D. Koontz W C. Septic arthritis in infants and children: a review of 117 cases. Pediatrics 1966; 38: 966-71.

16 Gustilo R B, Amren D P. Acute suppurative arthritis in children. Minn Med 1969; 2: 219-25.

17 Almquist $E$ E. The changing epidemiology of septic arthritis in children. Clin Orthop 1970; 68: 96-9.

18 Kolawole T M, Bohrer S P. Acute septic arthritis in Nigeria. A review of 65 cases involving the hip and shoulder joints. Trop Geogr Med 1972; 24: 327-38.

19 Nade S. Robertson F W. Taylor T K F. Antibiotics in the treatment of acute osteomyelitis and acute septic arthritis in children. Med J Aust 1974; 2: 703-5.

20 Morrey B F, Bianco A J, Rhodes K H. Septic arthritis in children. Orthop Clin North Am 1975; 6: 923-34.

21 Wiley J J, Fraser G A. Septic arthritis in childhood. Can J Surg 1979; 4: 326-30.

22 Peltola $\mathrm{H}$, Vahvanen V. A comparative study of osteomyelitis and purulent arthritis with special reference to aetiology and recovery. Infection 1984; 12: 75-9.

23 Anonymous. Septic arthritis in rheumatoid disease [Editorial] Br Med J 1976; ii: 1089-90.

24 Nakata M M. Lewis R P. Anaerobic bacteria in bone and joint infections. Rev Infect Dis 1984: 6 (suppl 1): 165-70S.

25 Kamme C. Lindberg L. Aerobic and anaerobic bacteria in deep infections after total hip arthroplasty. Differential diagnosis between infectious and non-infectious loosening. Clin Orthop 1981: 154: 201-7.

26 Staneck J L. Vincent S. Inhibition of Neisseria gonorrhoeae by sodium polyanetholesulfonate. J Clin Microbiol 1981; 13: 463-7.

27 Holmes K K. Gutman L T, Belding M E. Turck M. Recovery of Neisseria gonorrhoeae from 'sterile' synovial fluid in gonococcic arthritis. N Engl J Med 1971: 284: 318-20. 